\title{
Market Conditions for Additional Professional Education of Skilled Workers Under Neo- Industrialization of the Ural Region
}

\author{
Alexander Kokovikhin*, and Alexey Smirnov \\ Ural State University of Economics, 620144 Ekaterinburg, Russia
}

\begin{abstract}
The relevance of the research is due to the need to determine the balance of supply and demand in the formation of the competencies of skilled workers in the context of the introduction of a competence-based approach to human resource management. The purpose of the study is to determine the capacity of the market for programs to develop workers' competencies and the possibility of meeting this demand from additional education institutions. As a result of the study, it can be concluded that there is a constant demand for additional vocational education programs and relatively low intensity of competition in this market to form the competencies of skilled workers in the corporate sector of industry of the Ural Federal District.
\end{abstract}

\section{Introduction}

In modern conditions, there has been a transformation of the subject-object composition in the management of labor resources with the gradual transfer of the management subject functions from state authorities to the corporate sector. The non-state sphere of labor resources management is characterized by the use of adaptive complex management mechanisms, the implementation of which is possible within the framework of the institutional-competence approach. Coordination mechanisms of resource influence and social partnership, as well as methods of legal, financial and organizational regulation are to the forefront.

The peculiarity of using the institutional-competence approach in public management of human resources is the creation of the necessary qualitative characteristics of personnel by improving the process of formation and implementation of professional competencies. Continuity of the competency formation process is ensured by procedures for coordinating the formation of requests between the competency creation and application subsystems. In particular, there is a coordination of demand from corporate structures for specific competencies of highly qualified workers and proposals for the formation of these competencies by institutions of additional professional education. The main approaches to

\footnotetext{
* Corresponding author: kau@usue.ru
} 
the research methodology of this issue are considered in the works of $\mathrm{A}$. Yu. Kokovikhin and T. A. Kansafarova[1], T. A. Altukhova[2], J. JHeckman, J. Stixrud, and S. Urzua[3].

In the domestic practice of analyzing the process of forming professional competencies, survey methods are used, in particular, as a result of a questionnaire survey of participants in the competence formation system, which resulted in the conclusion that there are institutional barriers that distort information about both the demand for competencies and information about the competencies acquired by the employee. This conclusion made it possible to move to the task of finding statistical variables describing institutional barriers as an object of management in the system of formation and implementation of professional competencies.

The works of Saito Hisamitsu and Wu Jun Jie[4], Garcia Aziza and Levratto, Nadine[5], and Meliciani Valentina[6] provide examples of constructing econometric models that take into account institutional factors in the formation of regional employment disparities. The works of Saito Hisamitsu and Wu Jun Jie[4], Garcia Aziza and Levratto, Nadine[5], and Meliciani Valentina[6] provide examples of constructing econometric models that take into account institutional factors in the formation of regional employment disparities. It should be noted that the models presented are synthetic, including a set of "non-institutional" components related to politics and macroeconomic situation. Synthetic models determining the influence of institutional factors on imbalances in the system of formation and realization of professional competencies are also used in the works of Lucio Baccaro and DiegoRei [7] and Disparity between training and employment [8].

The implementation of additional vocational education programs is aimed at ensuring that the competencies of workers meet the modern requirements of the economy.

These programs are implemented for an adult audience with professional education and practical experience. An important task in the implementation of additional vocational education is to focus on existing professional standards and the performance of specific labor functions. Additional vocational education programs can be implemented in the form of advanced training programs lasting from 16 hours and in the form of retraining programs lasting from 250 hours.

\section{Methods}

The main methodology for estimating the capacity of these segments is a normative approach which allows obtaining the most conservative data on the demand for Educational Center services. The main methodology for evaluating the supply of additional education on the market was the analysis of organizations that implement additional education programs for programs similar to those of the Educational center based on the Registers of Licenses provided by regional executive authorities supervising education, and the subsequent search for information about programs on the websites of these educational organizations.

\section{Results}

To characterize the market capacity according to the segment "Additional professional education," we present data on the number of qualified workers at the enterprises of the Ural Federal District by occupation groups: electrical equipment electricians and repairmen, moulders, welders, rollers, structural metal preparators, machine operators, setup workers and related occupations, Table 1 . 
Table 1. The number of employees with the competencies of skilled workers at the enterprises of the Ural Federal District, 2020

\begin{tabular}{|c|c|c|c|c|}
\hline Row Names & $\begin{array}{c}\text { Kurgan } \\
\text { region }\end{array}$ & $\begin{array}{c}\begin{array}{c}\text { Sverdlovsk } \\
\text { region }\end{array} \\
\end{array}$ & $\begin{array}{c}\text { Tyumen } \\
\text { region }\end{array}$ & $\begin{array}{c}\text { Chelyabinsk } \\
\text { region }\end{array}$ \\
\hline \multicolumn{5}{|l|}{ Burner } \\
\hline & 19 & 162 & 93 & 683 \\
\hline \multicolumn{5}{|l|}{ Sharpener } \\
\hline & 48 & 216 & 278 & 373 \\
\hline \multicolumn{5}{|c|}{$\begin{array}{c}\text { Locksmith on Metalworking Equipment Repair } \\
\text { and Adjustment }\end{array}$} \\
\hline & 10 & 270 & 325 & 497 \\
\hline \multicolumn{5}{|l|}{ Toolmaker } \\
\hline & 106 & 864 & 371 & 435 \\
\hline Service technician & 19 & 594 & 232 & 248 \\
\hline Turner & 68 & 378 & 325 & 869 \\
\hline Milling-machine operator & 29 & 162 & 974 & 62 \\
\hline Grinder & 58 & 378 & 603 & 186 \\
\hline Electrician & 29 & 216 & 8580 & 435 \\
\hline Gear cutter & 19 & 108 & 510 & 683 \\
\hline Gear grinder & 48 & 270 & 835 & 621 \\
\hline \multicolumn{5}{|c|}{ Operator /numeric control machines adjuster } \\
\hline & 68 & 378 & 510 & 124 \\
\hline Lathe turner & 164 & 918 & 278 & 1118 \\
\hline Driller & 213 & 1188 & 278 & 683 \\
\hline Borer & 106 & 864 & 232 & 62 \\
\hline Electric welder & 116 & 648 & 186 & 124 \\
\hline Electric and gas welder & 106 & 864 & 46 & 373 \\
\hline \multicolumn{5}{|l|}{ Construction metal worker } \\
\hline & 19 & 108 & 139 & 186 \\
\hline \multicolumn{5}{|l|}{ Electrical fitter } \\
\hline & 261 & 1512 & 1252 & 497 \\
\hline \multicolumn{5}{|l|}{ Sling operator } \\
\hline & 126 & 702 & 139 & 124 \\
\hline Others & 242 & 1728 & 974 & 2732 \\
\hline Overall result & 1875 & 12525 & 17160 & 11115 \\
\hline
\end{tabular}

The estimated capacity of the market for this segment is 3200 million rubles with the cost of one employee training as much as 75000 rubles.

The evaluation of the proposal from organizations implementing additional vocational education programs according to the programs for the formation of competencies of skilled workers in the corporate sector of the Ural Federal District industry was carried out on the basis of the Registers of licenses granted by regional executive authorities supervising education and then searching for information on the programs of these educational organizations. The results are presented in table 2. 
Table 2. The number of additional vocational education organizations engaged in training programs for qualified workers, 2020.

\begin{tabular}{|c|c|c|c|}
\hline Territory & Higher education & $\begin{array}{c}\text { Secondary } \\
\text { vocational } \\
\text { education }\end{array}$ & $\begin{array}{c}\text { Private } \\
\text { organizations of } \\
\text { additional } \\
\text { vocational } \\
\text { education }\end{array}$ \\
\hline Kurgan region & - & 24 & 10 \\
\hline Sverdlovsk region & 2 & 85 & 16 \\
\hline Tyumen region & 1 & 20 & 12 \\
\hline Khanty-Mansi Autonomous Okrug & - & 30 & 36 \\
\hline Yamalo-Nenets Autonomous Area & - & 12 & 35 \\
\hline Chelyabinsk region & 2 & 73 & 117 \\
\hline Total UrFO & 5 & 244 & 8 \\
\hline
\end{tabular}

The structure of the offer on the market of additional education in the areas of pneumatic automatics, hydraulics, electrical installation, mechatronics, operations of numeric control machines, and the basics of knowledge in the field of working professions is represented by three groups of organizations.

Additional professional education in complex resource-intensive areas (pneumatic automation, hydraulics, mechatronics) is carried out in the centers of additional education of universities:

- in the Sverdlovsk region - the Ural Federal University and additional vocational education establishment International Institute of Technical Innovations, Mining University.

- $\quad$ in the Chelyabinsk region - the South Ural State University, Magnitogorsk State Technical University named after G.I. Nosov.

- $\quad$ in the Tyumen region - the Tyumen State University.

Additional professional education in electrical installation and basic knowledge in the field of working professions is carried out by secondary vocational education establishments and private organizations of additional vocational education.

It should be noted that the activity of secondary vocational education establishments in the implementation of additional vocational education programs is extremely low, as evidenced by the forms 1-SVE. Secondary vocational education organizations do not show themselves as active market participants and do not form a proposal of additional vocational education programs for a wide range of users. Private organizations of additional vocational education, with rare exceptions, carry out training on the basics of working specialties, forming dumping price proposals with an average course duration of 5 hours and a cost of 2500 to 5000 rubles.

Thus, one can conclude that there is relatively low intensity of competition in the market for additional vocational education in the following areas: pneumatic automation, hydraulics, electrical installation, mechatronics, operations of machines with numerical program control, and the basics of knowledge in the field of working professions. 


\section{Conclusions}

The study of supply and demand for the formation of competencies of skilled workers in the corporate sector of the Ural Federal District industry allows us to draw the following conclusions. The market capacity is quite significant due to the developed industrial complex in the Urals Federal District, the main territories with significant demand for these services are the Sverdlovsk and Chelyabinsk regions. The additional education market of the Ural Federal District can be classified as growing in almost all segments, and the total capacity will be more than 8 billion rubles by 2024, while maintaining the existing structure of consumer distribution between segments.

The structure of the proposal for the formation of competencies of skilled workers in the corporate sector of the Ural Federal District industry is represented by three groups of organizations: centers of additional vocational education at universities, secondary professional education organizations and private organizations of additional vocational education. Additional vocational education in complex resource-intensive areas is carried out in the centers of additional education of universities. It should also be noted that the activity of secondary vocational education in the implementation of additional vocational education programs is extremely low, as evidenced by the forms 1 - secondary vocational education. Organizations of secondary vocational education do not show themselves as active market participants; do not form a proposal of additional vocational education programs for a wide range of users. Private organizations of additional vocational education, with rare exceptions, carry out training on the basics of working specialties, forming dumping price offers with low course duration and low cost.

Thus, one can conclude that there is a constant demand for additional vocational education programs and a relatively low intensity of competition in this market to form the competencies of skilled workers in the corporate sector of the Ural Federal District industry.

\section{References}

1. A.Yu. Kokovikhin, T.A. Kansafarova, Manager, 3 (2018)

2. T.A. Altukhova, Competence management in the system of state authorities, Collection of scientific works SWorld, 2 (2013)

3. J.J Heckman, J.Stixrud, S. Urzua, Journal of Labor Economics, 3 (2006)

4. H. Saito, J. Wu,Agglomeration, Journal oregional science, 1(2016)

5. A. Garsaa, N. Levratto, Region et developpement (2018)

6. V. Meliciani, Regional disparities in the enlarged european union: geography, innovation and structural change, 13 (2016)

7. L. Baccaro, ReiInstitutional determinants of unemployment in OECD countries: A time series cross-section analysis (1960-98) (2005)

8. Disparity between training and employment. Cahiers vilfredo pareto, 17 (1979) 